\title{
TRANSFORMATION OF THE FUEL AND ENERGY COMPLEX IN THE CONTEXT OF DIGITALIZATION OF THE RUSSIAN ECONOMY
}

\author{
KHULUKSHINOV Denis ${ }^{1}$ \\ ${ }^{l}$ Scientific Research Institute of Natural Gases and Gas Technologies - Gazprom VNIIGAZ LLC, (Russian Federation) \\ E-mail: denis.rudn@gmail.com
}

\begin{abstract}
Ensuring the accelerated introduction of digital technologies in the economy and the social sphere is one of the national development goals of the Russian Federation for the period up to 2024 in accordance with the Decree of the President of the Russian Federation dated 07.05.2018 No. 204 and is enshrined as a priority area in the Strategy for Scientific and Technological Development of the Russian Federation.
\end{abstract}

Key words: digital technologies, fuel and energy complex, transformation, economy

JEL: P28

DOI: 10.5937/intrev2103036K

UDC: $330.341 .1(470)$

005.591.6:004]:620.9

COBISS.SR-ID 55064585 


\section{INTRODUCTION}

In order to digitally transform the industries of the fuel and energy complex of the Russian Federation (hereinafter - the Russian fuel and energy complex), creates conditions for the introduction of digital technologies and platform solutions in them, the Ministry of Energy of the Russian Federation (hereinafter - the Ministry of Energy of Russia) has formed a departmental project "Digital Energy" with the participation of company representatives the real sector of the economy in the areas of electric power, oil and gas complex, coal and peat industries.

The Digital Energy project takes into account the experience of the Russian fuel and energy complex in developing and implementing high-tech solutions, and also meets the main components of the Digital Economy national program in terms of developing an information security policy in a unified information environment, working with digital platforms, and developing a regulatory framework.

This project provides for the creation of a system for coordination and monitoring of the digital transformation of the Russian fuel and energy complex, within the framework of which a system of effective interaction between the Ministry of Energy of Russia, the expert community and business will be built on the basis of the creation of a center of competence in the main areas of energy digitalization, an expert coordinating body for digitalization of the fuel and energy complex, the Council for digital transformation of the industry.

\section{MATERIALS AND METHODS}

In preparing the materials, there were used strategic planning documents (Decree of the President of the Russian Federation dated 07.05.2018 No. 204 "On national goals and strategic objectives of the development of the Russian Federation for the period up to 2024", the program "Digital Economy of the Russian Federation", Strategy of scientific and technological development of the Russian Federation), data from the Ministry of Energy of Russia regarding the digitalization of energy and the departmental project "Digital Energy" and companies of the Russian fuel and energy complex regarding the implementation of digital technologies [1-13].

The article reflects information on global trends in the field of electricity generation and the market of digital technologies in the energy sector, as well as the implementation of measures for the digital transformation of the industry, including the structure of the departmental project "Digital Energy" for 20182024, creating conditions for the development and development digital services and solutions, a system for coordinating and monitoring digital transformation, digitalization of the electric power industry, oil and gas complex, coal industry and the expected effect for the Russian fuel and energy complex [1-13].

\section{RESULTS}

In modern conditions, digitalization makes it possible to manage more complex power systems, which contributes to the development of a wide range of new technologies, including distributed generation.

In 2021, it is planned to commission new distributed power generation capacities in the world in the amount of about 200,000 MWt (thermal megawatt), centralized - 100,000 MWt. Until 2025, it is expected that the commissioning of capacities for distributed generation will exceed 250,000 MWt, and for centralized generation it will be less than 100,000 MWt (Fig. 1) [13]. 


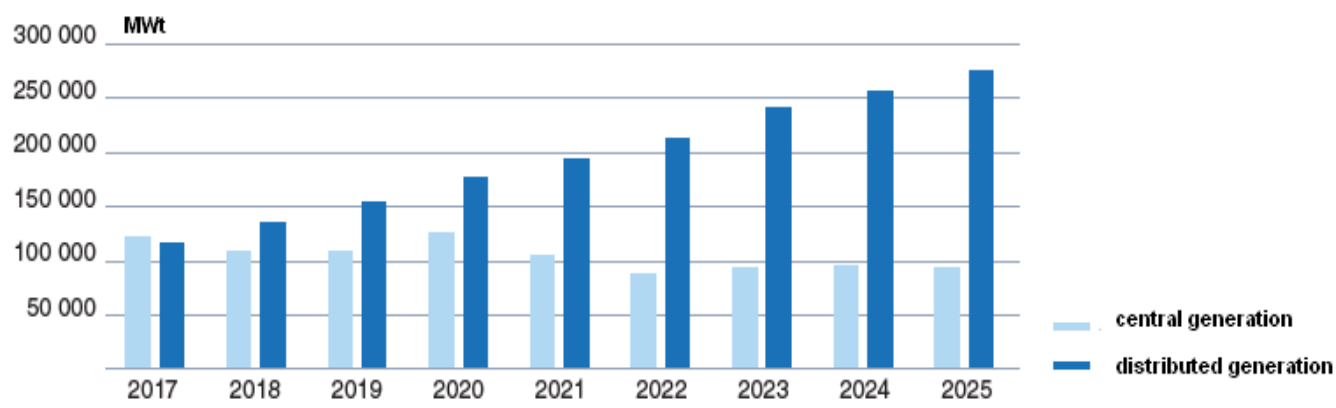

Fig. 1. Forecast of commissioning of new power generation capacities in the world for 2017-2025

The total global size of the digital technologies market in the energy sector in 2020 amounted to more than 100 billion dollars, of which the bulk of funding is directed to smart electricity meters in the amount of 21 billion dollars (20\%), as well as to the operation and maintenance of thermal power plants in the amount of 19 billion dollars (18\%). By 2025, this figure will exceed the 125 billion dollars (Fig. 2) [13].

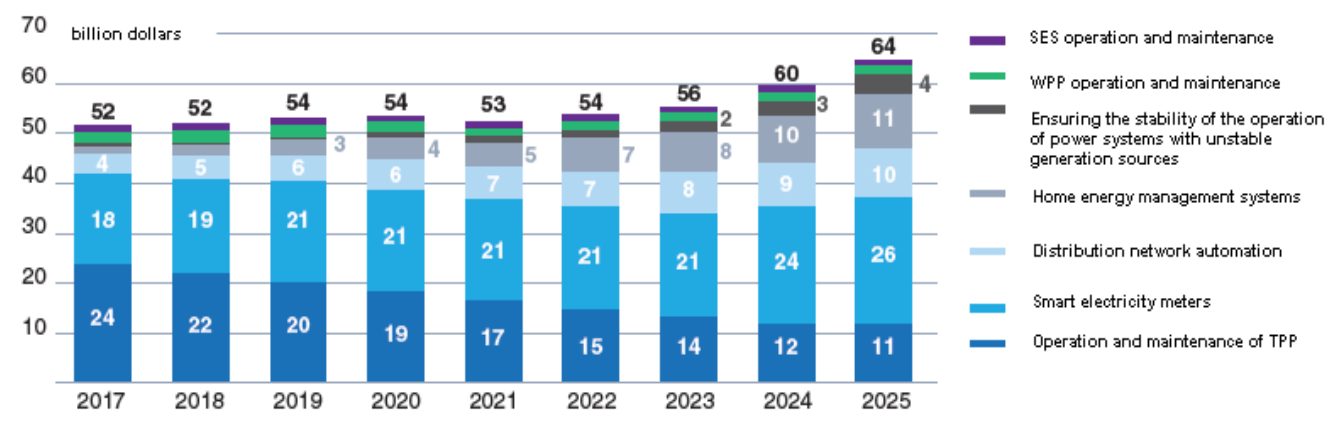

Fig. 2. The world market of digital technologies in the energy sector for 2017-2025

In accordance with the Decree of the President of the Russian Federation dated 07.05.2018. No. 204 "On national goals and strategic objectives of the development of the Russian Federation for the period up to 2024", it is determined that the transformation of priority sectors of the economy, including energy infrastructure, is carried out through the introduction of digital technologies and platform solutions, and also secured the guaranteed provision of affordable electricity, including through the introduction of intelligent systems for managing the electric grid sector based on digital technologies [2].

Currently, there are "smart" wells and "smart" fields in the oil and gas sector, virtual monitoring and forecasting systems for the state of generating equipment, digital dispatching of power facilities are being introduced in the electric power industry, sensors and portable devices are used in the coal industry.

The largest Russian fuel and energy companies are actively introducing digital technologies, which are shown in Table 1 [13].

Table 1. Implementation of digital technologies by Russian fuel and energy companies

\begin{tabular}{|l|l|l|}
\hline No. & Organization name & Digital technology \\
\hline 1 & PJSC NK Rosneft & $\begin{array}{l}\text { Cloud Computing Model; } \\
\text { "Intellectual field"; } \\
\text { "Smart Well". }\end{array}$ \\
\hline 2 & PJSC Lukoil & $\begin{array}{l}\text { Modeling based on Big Data; } \\
\text { Center for spatial visualization; } \\
\text { "Intellectual field"; } \\
\text { "Smart Well". }\end{array}$ \\
\hline 3 & PJSC TATNEFT & $\begin{array}{l}\text { Engineering Center; } \\
\text { "Smart Well". }\end{array}$ \\
\hline 4 & PJSC Gazprom & $\begin{array}{l}\text { Engineering Centers } \\
\text { (Gazprom VNIIGAZ LLC, etc.); } \\
\text { "Intellectual field". }\end{array}$ \\
\hline 5 & PJSC Gazprom Neft & $\begin{array}{l}\text { Analysis of geological information Geomate; } \\
\text { "Digital twin" of the refinery; } \\
\text { "Smart Well"; } \\
\text { Automated control center; }\end{array}$ \\
\hline
\end{tabular}




\begin{tabular}{|l|l|l|}
\hline & \multicolumn{1}{|c|}{} & Implementation of the industrial Internet. \\
\hline 6 & JSC "Siberian Coal Energy Company" & $\begin{array}{l}\text { "Intellectual Courier" } \\
\text { A complex of intelligent systems to ensure work safety. }\end{array}$ \\
\hline 7 & PJSC Rosseti & $\begin{array}{l}\text { Smart metering devices; } \\
\text { "Smart Grids"; } \\
\text { Digital substations. }\end{array}$ \\
\hline 8 & $\begin{array}{l}\text { Federal Grid Company of the Unified } \\
\text { Energy System, PJSC }\end{array}$ & Telecontrol of substation equipment. \\
\hline 9 & JSC "ROTEK" & $\begin{array}{l}\text { Digital system for predicting the state of equipment of gas } \\
\text { power plants. }\end{array}$ \\
\hline
\end{tabular}

The departmental project "Digital Energy" involves the joint participation of the state and business structures at all stages of its implementation, which will allow removing administrative barriers and more effectively implementing the developed digital standards and platforms. As part of the project, it is also envisaged to create a unified goal-setting system from the level of the industry regulator to the institution of digital transformation managers in companies (Chief Digital Transformation Officer) [6, 12].

When carrying out the digital transformation of the Russian fuel and energy complex, the most important task of the Ministry of Energy of Russia is to create a single information space for energy entities, taking into account the emerging conditions and requirements for the creation of new services, platforms and technologies.

The structure of the departmental project "Digital Energy" for 2018-2014., includes [6, 12, 13]:

Improving the efficiency of the Russian fuel and energy complex through the use of digital technologies and platform solutions;

- Digitalization of the electric power industry;

- Digitalization of the oil and gas complex;

- Digitalization of the coal industry.

In this context of the direction "Improving the efficiency of the Russian fuel and energy complex through the use of digital technologies and platform solutions", a number of measures are envisaged aimed at creating conditions for the development and development of digital services, conducting strategic monitoring of the implementation of the concept of digitalization of the industry, training personnel for digital energy, developing a regulatory framework.

Within the framework of the "Digitalization of the electric power industry" direction, it is planned to implement risk-oriented management, create a system for the formation of industry orders and an industry digital platform. This will reduce logistics costs and transfer process data in real time.

As part of the areas "Digitalization of the oil and gas complex" and "Digitalization of the coal industry", pilot projects for the introduction of digital technologies and industry platform solutions will be implemented, as well as work will be carried out to develop and amend industry legislation.

By 2024, within the framework of creating conditions for the development and development of digital services and solutions in the Russian fuel and energy complex, target indicators have been set and the following tasks have been set, indicated in Table 2 [13].

Table 2. Targets and objectives of the departmental project "Digital Energy" until 2024

\begin{tabular}{|l|l|}
\hline Targets by 2024 & $\begin{array}{l}\text { Share of Russian fuel and energy companies that use information } \\
\text { security means when they are transmitted over the Internet }\end{array}$ \\
\hline $100 \%$ & $\begin{array}{l}\text { The share of key organizations in the fuel and energy complex that } \\
\text { use digital technologies and platforms as part of the functioning of } \\
\text { the unified information environment of the fuel and energy } \\
\text { complex of Russia }\end{array}$ \\
\hline up to $14 \%$ & $\begin{array}{l}\text { The share of Russian fuel and energy companies that use advanced } \\
\text { production technologies will grow }\end{array}$ \\
\hline $11 \%$ & $\begin{array}{l}\text { The share of specialists in information and communication } \\
\text { technologies in the organizations of the Russian fuel and energy } \\
\text { complex }\end{array}$ \\
\hline
\end{tabular}




\begin{tabular}{|c|c|}
\hline by $7 \%$ & $\begin{array}{l}\text { The costs of personnel training by organizations of the Russian fuel } \\
\text { and energy complex in the field of information and communication } \\
\text { technologies will increase }\end{array}$ \\
\hline Tasks & Expected results \\
\hline $\begin{array}{l}\text { Creation of a management system for the } \\
\text { coordination of digital transformation of the } \\
\text { Russian fuel and energy complex }\end{array}$ & $\begin{array}{l}\text { A conceptual basis for the digital transformation of the Russian fuel } \\
\text { and energy complex has been developed; } \\
\text { The Council for Digital Transformation of the Russian Fuel and } \\
\text { Energy Complex was created; } \\
\text { Created a project office for the implementation of the departmental } \\
\text { project "Digital Energy"; } \\
\text { Centers of competence have been created in the main areas of } \\
\text { digitalization of the fuel and energy complex. }\end{array}$ \\
\hline $\begin{array}{l}\text { Formation of conditions for the creation } \\
\text { and development of a unified information } \\
\text { environment for the Russian fuel and } \\
\text { energy complex }\end{array}$ & $\begin{array}{l}\text { Formulated requirements for the development of platform solutions } \\
\text { within a single information environment; } \\
\text { A model of a unified energy information environment has been } \\
\text { developed; } \\
\text { Creation of a center for support, storage and development of } \\
\text { uniform national industry standards; } \\
\text { A legal framework has been prepared. }\end{array}$ \\
\hline Providing training for digital energy & $\begin{array}{l}\text { Developed sectoral educational programs and retraining programs } \\
\text { for digital energy; } \\
\text { At least } 5 \text { branch educational centers on the basis of higher } \\
\text { educational institutions have been created and are functioning. }\end{array}$ \\
\hline $\begin{array}{l}\text { Digital public administration and control } \\
\text { and supervisory activities in the Russian } \\
\text { fuel and energy complex }\end{array}$ & $\begin{array}{l}\text { The provision of public services and the implementation of the } \\
\text { control and supervisory functions of the Ministry of Energy of } \\
\text { Russia are carried out in accordance with the technological and } \\
\text { regulatory requirements of the legislation; } \\
\text { State systems for collecting information on the activities of Russian } \\
\text { fuel and energy facilities are integrated into the National Data } \\
\text { Management System. }\end{array}$ \\
\hline
\end{tabular}

The system of coordination and monitoring of digital transformation will be carried out by the Ministry of Energy of Russia jointly with the project office for the implementation of the departmental project, the Council for Digital Transformation of the Russian Fuel and Energy Complex and centers of competence (Fig. 3) [13].

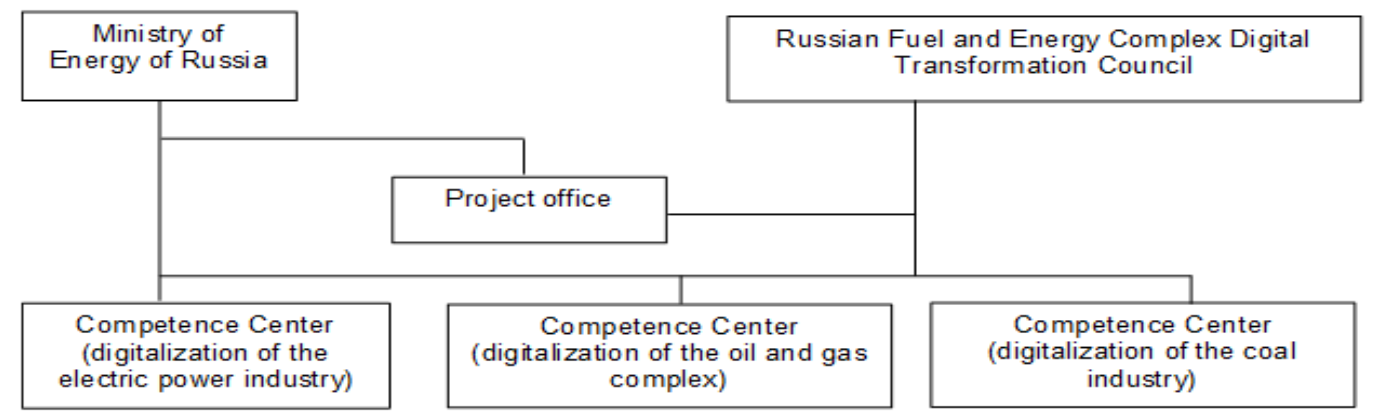

Fig. 3. The system of coordination and monitoring of digital transformation of the Russian fuel and energy complex

As a result of the digital transformation of the Russian fuel and energy complex in the electric power industry, the oil and gas complex and the coal industry, there should be the following effect for these sectors of the economy (Table 3) [13]. 
Table 3. Key effects of digitalization of the Russian fuel and energy complex

\begin{tabular}{|l|l|}
\hline Name & Effect Description \\
\hline $\begin{array}{l}\text { Power } \\
\text { engineering }\end{array}$ & $\begin{array}{l}\text { Reducing the duration of power outages and the average frequency of technological } \\
\text { disturbances (SAIDI / SAIFI) by 5\% by 2024; } \\
\text { Increasing the level of technical condition of production assets of the electric power industry } \\
\text { for facilities by 5\% by } 2024 \text { without increasing the cost of maintaining the technical condition; } \\
\text { Reduction by } 20 \% \text { of accidents at power facilities related to the technical condition of } \\
\text { production assets by 2024. }\end{array}$ \\
\hline $\begin{array}{l}\text { Oil and gas } \\
\text { complex }\end{array}$ & $\begin{array}{l}\text { Increase in the oil recovery factor by 5-10\% in "digital fields"; } \\
\text { Decrease in operating costs in digital fields by 10\%; } \\
\text { Reducing capital expenditures on digital fields up to } 15 \% .\end{array}$ \\
\hline Coal industry & $\begin{array}{l}\text { Increase in mining and quarrying by 5-7\% by 2024; } \\
\text { Improving the safety level of mining operations. }\end{array}$ \\
\hline
\end{tabular}

\section{CONCLUSION}

The digital transformation of the Russian fuel and energy complex on the basis of strategic planning documents and the departmental project of the Ministry of Energy of Russia "Digital Energy" until 2024 will allow creating a unified digital environment in the field of electric power, oil and gas complex and coal industry.

This will contribute to the development of digital services and solutions in the Russian fuel and energy complex and will create a system for coordinating and monitoring digital transformation, which will reduce operating, capital costs and accidents at facilities, as well as improve the technical condition of production assets, increase the oil recovery factor and increase underground coal production.

\section{REFERENCES}

[1] Decree of the President of the Russian Federation dated 01.12.2016 No. 642 "On the Strategy of Scientific and Technological Development of the Russian Federation".

[2] Decree of the President of the Russian Federation of 07.05.2018 No. 204 "On national goals and strategic objectives of the development of the Russian Federation for the period up to 2024".

[3] National program "Digital Economy of the Russian Federation" (approved by the minutes of the meeting of the Presidium of the Council under the President of the Russian Federation for Strategic Development and National Projects No. 7 dated 04.06.2019).

[4] Chebotarev, N. (2020). Digital economy of the oil and gas industry of the Russian fuel and energy complex. Monograph. p. 80.

[5] Gnezdova, Y., Romanova, Y. (2018). Prospects for the digital sectoral economy of Russia: features and conditions. Collective monograph. p. 164.

[6] Kulapin, A. Departmental project of the Ministry of Energy of Russia "Digital Energy" [Electronic resource] https://www.eriras.ru/files/2._kulapin_a.i._vedomstvennyy_proekt_minenergo_rossii_tsifrovaya_energetika.docx.

[7] Mitrofanova, I., Ryabova, I., Fetisova, O. (2019). Digitalization of the economy: world, Russia, regions. Monograph. p. 73.

[8] Mozokhin, A., Shvedenko, V. (2019). Analysis of the use of the development of digitalization of domestic and foreign energy systems. Scientific and technical bulletin of information technologies, mechanics and optics 19 (4). pp. 657-672.

[9] Rogalev, N. (2019). Digital energy: a new paradigm of functioning and development. Collection, $300 \mathrm{p}$.

[10] Safiullin, R. (2019). Digitalization of the fuel and energy complex. Scientific almanac 5-2 (55), pp. 85-86.

[11] Zhdaneeva, O. (2020). Questions of the technical policy of the fuel and energy complex of the Russian Federation. Monograph. p. 304.

[12] Ministry of Energy of the Russian Federation. Departmental project "Digital Energy" [Electronic resource] https://minenergo.gov.ru/node/14559.

[13] Ministry of Energy of the Russian Federation. Digitalization of the energy sector [Electronic resource] https://in.minenergo.gov.ru/energynet/vedomstvennyi-proekt-tsifrovaya-energetika/.

Article history:

Received 10 April 2021

Accepted 17 September 2021 